\title{
Modelling Associative-Semantic Content as Regards the Logic-of-Semantics Dimension of the Adolescents' Speech
}

\section{Моделювання асоціативно-семантичного контенту у логіко-смисловому вимірі мовлення підлітків}

\author{
Natalya Tokareva \\ Dr. hab. in Psychology, \\ Assistant Professor, \\ Head of Common and Age \\ Psychology Faculty
}

\author{
Наталя Токарева \\ доктор психологічних наук, \\ доцент, \\ завідувач кафедри загальної \\ та вікової психології
}

E-mail: tokareva152681@,gmail.com
orcid.org/0000-0003-1428-3729

Kryvyi Rih State Pedagogical University

54, av. Gagarin, Кгуvуi Rih, Dnepropetrovsk Reg., Ukraine, 50086
Криворізький державний педагогічний університет $\bowtie$ пр. Гагаріна, 54, м. Кривий Ріг,

Дніпропетровська обл., Україна, 50086

Original manuscript received February 28, 2019

Revised manuscript accepted September 15, 2019

\begin{abstract}
Objective. The article deals with the analysis of the trends in the logic of the semantic organization of the speech and mental activity of adolescents as regards the dimension of the available semantic environment and that of the speech competences of an individual. It is stated that information about the world is systematized by human consciousness in the form of an associative-verbal field, whose producing and modelling is one of the ways of representing the speech competence of an individual shaping his/her destiny.
\end{abstract}


Materials \& Methods. In view of the above, an empirical research of the distinctive features of expanding semantic content of the adolescents' speech consciousness as regards the dimension of the logic-of-semantics organization of the mental and speech activity was performed using the diagnostic potential of a free associative experiment. A system of relevant ways of construction and associative expansion of meanings in the semantic field of the speech consciousness of adolescents was chosen as the subject of the research.

Results. Drawing on the results of the frequency analysis of the use of typical associative patterns for organizing the semantic field of speech, it was stated that the most represented among adolescents is a semantic way of reasoning based on the identification signs of the general contour of the trigger word at the level of its meaning. It was proved that the greatest changes in the logic of expanding associative semantic content are observed among older adolescents, which is interpreted as the result of fundamental changes in the strategies for cognitive processing of information flows.

Conclusions. A conclusion was drawn about the stable tendency towards the standardization and unification of speech in adolescents during their transition to adulthood, and the reduction in the heuristic resource of the intellectual activity of older adolescent pupils was noted. In this context, the purposeful formation of speech and mental competences of an individual, the acquisition by adolescents of efficient methods of the logic-of-semantics organization of the associative semantic content of speech is defined as a necessary prerequisite for the personality development, as well as that for the speech and mental development of an individual.

Key words: speech and mental activity, speech consciousness, logical-semantic organization of the text, reasoning, associative link, free associative experiment, adolescence, speech development.

\section{Вступ}

Розвиток цивілізації у континуальному вимірі сучасного інформаційного суспільства характеризується глобальними трансформаціями універсальної матриці світосприймання, інтенсивністю субкультурної стратифікації, кризою колективної ідентичності. Стратегічна доступність для широких верств населення багаторівневої інформації, радикальне перетворення просторових і часових координат генези буття у мультикластерних Internet-мережах обумовлюють суттєве ускладнення контексту особистісного становлення людини, і зокрема - у підлітковому віці, що є складним переламним етапом завершення дитинства й інтенсивного форматування персонологічного профілю дорослості. 
Під впливом нових соціокультурних вимірів життєтворення у ментальному просторі підлітків формується новий (гнучкоадаптивний в умовах невизначеності) тип світогляду, змінюється система уявлень щодо себе, характер і особливості самопрезентації, зростає когнітивно-афективна насиченість і диференційованість міжособистісних контактів. Важливу роль для розуміння цілісної природи генези дорослішання особистості відіграє усвідомлення траєкторій мовно-мовленнєвого розвитку соціолекту підлітків як своєрідної психолінгвістичної субкультури, в межах якої знаходять відображення норми та цінності, котрі домінують у молодіжному середовищі та $\epsilon$ орієнтирами для вербальної i невербальної поведінки; означене цілком узгоджується із концепцією виявлення властивостей і рис особистості у мовленні (Фомина, 2014; Фомина \& Орлов, 2017) та принципами системно-інтегративного підходу до комунікативного моделювання особистісних конструктів суб'єктів життєтворення (Токарева, 2015). Адже концептосфера мовлення розглядається науковцями (Ахутина, 2016; Зінченко, 2016; Караулов, 2010; Смульсон, 2003; Spätgens \& Schoonen, 2017 та ін.) як семіотичний симбіоз соціокультурного контенту буття та свідомості людини, поєднаних логіко-смисловими зв'язками у ментальному просторі суб'єктивного досвіду особистості. Ментальна модель світобачення (мовний концепт світу) беззаперечно є відображенням суб'єктивних властивостей мовної особистості, концептуалізація яких детермінована об'єктивними законами світу, авторизованими висловлюваннями (та/або текстами) носіїв мовлення та актуальними для конкретної особистості або субкультурної групи способами мовної репрезентації логіко-смислових утворень (Бабенко, Васильев \& Казарин, 2000; Чепелева, 2005). У даному контексті не викликає сумнівів актуальність уваги психологів, філологів, психолінгвістів до проблем логіко-смислової організації мовленнєвомисленнєвої діяльності особистості, полімодальний ресурс котрої дозволяє подолати бінарну оппозицію афекту й інтелекту (Леонтьев, 2007). Інтерпретація мовленнєво-мисленнєвої діяльності у площині соціокультурної активності, що виявляється не лише у предметно-денотатному змісті висловлювання, а й, переважно, у суб'єктивному ставленні особистості до вибору форм означення i конструювання даного змісту, пов'язує логіку психолінгвістичних 
досліджень із здатністю особистості до мовленнєвих імпровізацій (Chrabaszcz \& Gor, 2017; Ахутина, 2016; Ушакова, 2011; Фомина, 2014), використання адекватних цілям і ситуаціям спілкування засобів жанрового оформлення висловлювань у вимірах доступного семантичного простору та мовленнєвих компетентностей мовної особистості (Fairclough, 1995; Frank \& Christiansen, 2018; Ishida, 2018; Spätgens \& Schoonen, 2017; Бабенко, Васильев \& Казарин, 2000; Леонтьев, 2007).

Вагоме місце у проблемному полі досліджень логікосмислової організації мовленнєво-мисленнєвої діяльності займають результати вивчення асоціативних схем моделювання мовлення як логіко-семантичної форми розширення смислових конструалів суб' єктивного мовного простору людини (Завершнева, 2015; Караулов, 2010; Романова, 2017; Токарева, 2015; Ушакова, 2011). У площині трансформаційної (генеративної) граматики Н. Хомського (Chomsky, 1968), зокрема, доведено, що процес перетворення глибинних структур мовлення у поверхневі структури (слова, знаки, символи) є послідовною серією трансформацій, котрі слугують фільтрами первинного досвіду особистості й супроводжуються частковим перетворенням (розширенням, втратою або викривленням) інформації. У критичному дискурсаналізі N. Fairclough (1995) активно досліджується можливість змінення семіотичних мовленнєвих систем особистості (їня динаміка) у процесі вибудовування нових комбінацій суб'єктивного досвіду. Водночас аналіз наукової літератури засвідчив відсутність сучасної інтегративної теорії мовленнєвого розвитку особистості у період дорослішання, недостатньо уваги приділяється й психолінгвістичному аналізу текстових утворень підлітків, хоча кожне мовленнєве висловлювання (текст) $є$ проекцією ментального контенту конкретної мовної особистості, котра володіє системою мови і готова до мовленнєвих вчинків. Абсолютно погоджуємося iз тезою Ю.М. Лотмана, котрий наголошує: «Культурне освоєння світу людиною - це вивчення його мови, дешифрування цього тексту, переклад його доступною людині мовою» (Лотман, 2010: 398). За допомогою мовлення і мови «люди виражають зміст свого внутрішнього психічного світу» (Ушакова, 2011: 74), а тому розуміння вимірів концептуалізації підлітками дійсності у мовних інтенціях, зокрема й асоціативних, $є$ необхідною умовою оптимізації 
психолого-педагогічного супроводу особистісного становлення дитини у кризові періоди генези буття.

Зважаючи на дискусійний контент означеної проблеми, а також усвідомлюючи важливість розуміння тенденцій компетентнісного розвитку сучасного підлітка в системі психолого-педагогічного супроводу навчально-виховного процесу, у даному дослідженні ми мали за мету конкретизацію тенденцій моделювання та асоціативного розгортання семантичного контенту у логікосмисловому вимірі мовлення підлітків.

\section{Методи і методики дослідження}

Результати теоретичного аналізу динаміки розвитку мисленнєво-мовленнєвої діяльності підлітків дозволяють констатувати, що інформація про світ систематизується свідомістю людини у вигляді семантичного (асоціативно-вербального) поля (фрейма, семантичної сітки), продукування і моделювання якого є одним із засобів репрезентації мовної компетентності суб'єкта життєтворення. У площині означеного нами було зорганізовано й виконано емпіричне дослідження особливостей розгортання семантичного контенту мовної свідомості підлітків у вимірі логіко-смислової організації мисленнєво-мовленнєвої діяльності за допомогою діагностичного потенціалу вільного асоціативного експерименту.

Вільний асоціативний експеримент $\epsilon$ одним із визнаних науковою спільнотою способів виявлення об'єктивно існуючих у психіці носія мови семантичних зв'язків між словами, а також - означення лінгво-культурологічної специфіки мовленнєвої поведінки особистості. Використовуючи метод вільних асоціацій у логіці психолінгвістичних досліджень, ми поділяємо позиції коннекціонізму, вихідною тезою котрого є принцип паралельного опрацювання інформації (Parallel Distributed Processing), що забезпечує можливість застосування даного методу не лише для встановлення зв'язків між двома конкретними словами, а й для визначення відповідного певному слову зразка (паттерна) активації певного сегменту семантичного поля мовної свідомості.

Вибір вільного асоціативного експерименту як методу емпіричного дослідження у контексті даної роботи зумовлений 
його відповідністю цілям дослідницької програми, активним режимом функціонування мовної свідомості респондентів при перекодуванні мовного знаку у персоніфіковану смислову форму; вільний асоціативний експеримент знижує імовірність тлумачення асоціативного концепту крізь призму особистісного досвіду дослідника, надаючи для аналізу матеріал, отриманий від носіїв мови із різним суб'єктивним досвідом і рівнем культури.

Вибірку емпіричного дослідження склали 492 учні 6-9-х класів загальноосвітніх шкіл м. Кривого Рогу (Україна); вік респондентів (11-15 років) детермінований особливостями генези підліткового етапу розвитку у системі освітнього простору. За способом відбору респондентів вибірку слід вважати випадковою, що дозволяє виключити навмисне викривлення характеристик генеральної сукупності даних.

Предметом дослідження була обрана система актуальних способів моделювання асоціативного контенту смислів у семантичному полі мовної свідомості підлітків.

Гіпотеза емпіричного дослідження означила припущення щодо значущості відмінностей розгортання логічних схем організації асоціативно-семантичного контенту мисленнєво-мовленнєвої діяльності між підлітками різних вікових груп.

Процедура дослідження передбачала емпіричне вивчення системи асоціативно-смислових зв'язків у площині логіко-смислової організації мовлення підлітків. Респондентам пропонувалося реагувати на слова-стимули (або послідовність мовних знаків) асоціацією (та/або асоціативним рядом), що першою виникає у свідомості й $є$ формулою смислу. Відтворення асоціативного концепту (як конкретного випадку розгортання мовленнєвої події (Fairclough, 1995), зорієнтованої на відображення нуклеарної семантики слів логогеном (Ушакова, 2011: 215) і синтезування адекватного смислового конструкту) потребувало від підлітків актуалізації універсального динамічного коду вербально-когнітивної системи: осмислення i категоризації структурних елементів заданого семантичного поля, встановлення асоціативно-смислових зв'язків між елементами семантичного конструалу, вибір найбільш коректної форми смислотворення та конструктивного розгортання знакового образу у межах доступного мовного досвіду. Разом з тим, вихідним матеріалом для вивчення ми вважали не мовну семантику 
асоціативного ряду, а мовну свідомість респондентів, котра «складається із стандартно організованих елементарних одиниць притаманних носіям мови знань про світ» (Романова, 2017: 45). Аналізу підлягала репрезентація асоціативно-смислового контенту відповідного семантичного ряду (денотативне представлення змістових одиниць одного асоціативно-семантичного конструалу), повторюваність лексем, частотність типових вербальних реакцій серед респондентів (вираховувалися абсолютна частота способу смислоутворення), що дозволило певною мірою реконструювати семантичне поле форматування логіко-смислового виміру мовлення респондентів і виявити рівень активності підлітків при утворенні асоціацій.

Первинна обробка даних здійснювалася методом контентаналізу із подальшим обчисленням середньостатистичних значень отриманого матеріалу. При узагальненні та аналізі результатів емпіричного зрізу була використана комп'ютерна статистична програма IBM SPSS Statistics 19 («Statistical Package for the Social Science»).

\section{Результати та дискусії}

Предметне поле даного дослідження дозволяє нам інтерпретувати утворення асоціацій як перенесення концептуального змісту знаків однієї системи (зокрема - знаків семантичного поля певної лексеми) до іншої логіко-семантичної системи знаків, що супроводжується варіативними модифікаціями (звуженням, розширенням, актуалізацією базового смислу) концептуальної складової вихідного слова.

Узагальнені результати виявлення ключових способів смислотворення та тенденцій асоціативного розширення семантичного поля у межах логіко-смислової структури мовлення в порівнюваних групах підлітків вибіркової сукупності наведені у таблиці 1.

Аналіз кількісних показників абсолютної частоти (absolute frequency) використання полімодальних способів асоціативного смислотворення підлітками засвідчив домінування у семантичному вимірі асоціативних семем культурно-первинних (типових) 
відповідей; найменш частотними є, відповідно, суб'єктивні асоціації ідеосинкразичного (креативного, афективно-когнітивного) типу, що може бути обумовлено як віковими особливостями респондентів, так і загальним прагматичним спрямуванням світоглядних позицій сучасного суспільства.

Таблиця 1. Показники частотності використання способів асоціативного смислотворення підлітками

\begin{tabular}{|c|c|c|c|c|}
\hline \multirow[b]{3}{*}{ Типи асоціацій } & \multicolumn{4}{|c|}{ Вікові групи респондентів } \\
\hline & $\begin{array}{c}\text { 11-12 років } \\
(\mathrm{n}=123)\end{array}$ & $\begin{array}{c}13 \text { років } \\
(\mathrm{n}=118)\end{array}$ & $\begin{array}{c}14 \text { років } \\
(\mathrm{n}=126)\end{array}$ & $\begin{array}{c}15 \text { років } \\
(\mathrm{n}=125)\end{array}$ \\
\hline & \multicolumn{4}{|c|}{$\begin{array}{c}\text { Частотність (absolute frequency) способів } \\
\text { асоціативного смислотворення }\end{array}$} \\
\hline \multicolumn{5}{|c|}{ Формальні асоціації } \\
\hline Об’єктивно-фонетичні & 0.3 & 0.9 & 3.6 & 1.8 \\
\hline Стереотипно-лексичні & 1.9 & 0.7 & 7.2 & 8.8 \\
\hline \multicolumn{5}{|c|}{ Семантичні асоціації } \\
\hline Семантично подібні & 3.3 & 3.9 & 5.8 & 5.7 \\
\hline Семантичного контрасту & 0.4 & 1.5 & 7.1 & 2.5 \\
\hline Семантично суміжні (приналежності) & 39.1 & 41.8 & 33.0 & 32.4 \\
\hline Семантично суміжні (підпорядкування) & 10.5 & 13.7 & 5.7 & 6.4 \\
\hline Семантично суміжні (тотожності) & 16.8 & 18.8 & 7.9 & 3.4 \\
\hline $\begin{array}{l}\text { Семантично суміжні } \\
\text { (логічної ад'єктивації) }\end{array}$ & 8.5 & 7.1 & 11.1 & 13.7 \\
\hline \multicolumn{5}{|c|}{ Суб’сктивні (ідеосинкразичні) асоціації } \\
\hline Емоційно-оціночні & 0.6 & 0.3 & 2.4 & 1.6 \\
\hline Креативні & 0.6 & 0.5 & 3.2 & 5.0 \\
\hline \multicolumn{5}{|c|}{ Синтагматичні асоціації } \\
\hline $\begin{array}{l}\text { Синтаксичні конструкції } \\
\text { (словосполучення) }\end{array}$ & 6.2 & 1.4 & 10.6 & 10.5 \\
\hline $\begin{array}{l}\text { Синтаксичні конструкції } \\
\text { (речення) }\end{array}$ & 3.7 & 0.7 & 0.2 & 0 \\
\hline
\end{tabular}

Подальше ранжирування частотності використання асоціативних схем смислоутворення (були враховані перші три рангові позиції) дозволило констатувати, що найбільш представленим серед підлітків $є$ семантичний спосіб смислотворення, котрий базується на ідентифікаційних ознаках загального контуру словастимула на рівні значення. Такий спосіб смислотворення потребує розуміння (усвідомлення) значення похідних слів та асоціативного розгортання їх смислового контенту; відповідно, при утворенні асоціативної пари між словом-стимулом i реакцією на нього 
респондентами встановлюється смисловий зв'язок, котрий потребує достатнього (продуктивного) рівня інтелектуальної активності.

Диференціація асоціативного контенту даного семантичного поля виявила домінування асоціативних зв'язків, утворених за типом семантичної суміжності, і зокрема - приналежності (abs_freq 41.8-32.4): суміжність у часі (день - година, ранок - полудень) або у просторі (ліс - полювання, дерево - листя). Асоціативне смислотворення із урахуванням принципу семантичної суміжності потребує від носіїв мови логічного структурування смислових зв'язків між словами-асоціатами, а отже - асоціативна пара форматується на основі аналізу глибинних ярусів значення i розуміння логіко-смислового контексту асоціативно-смислового поля похідного слова. Дана категорія асоціацій широко представлена у відповідях підлітків усіх вікових груп (11-15 років), що засвідчує здатність респондентів до виконання мовленнєво-мисленнєвої діяльності на високому рівні інтелектуальної активності.

Доволі частотними у полі асоціативного смислотворення респондентів молодшого та середнього підліткового віку (11-12 та 13 років) $є$ також відповіді, утворені за типом семантичної тотожності (abs_freq 18.8-16.8) та семантичного підпорядкування (abs_freq 13.7-10.5), що також потребують навичок оперування логічними категоріями. Так, тематична тотожність слів-асоціатів визначається спільними процесами семантичної деривації, що об'єднують у даній групі лексико-семантичні варіанти слів за принципом аналогії, перетину експліцитних та імпліцитних значень (наприклад, горе - біда). Актуалізація семантичного простору мовної свідомості у площині логічного підпорядкування зумовлює часткову заміну елементарних компонентів значення похідного слова на суміжні семи, що не були експліцитно виражені у словістимулі, але можуть бути семантично виведені 3 нього шляхом асоціативного смислотворення у логіко-смилових вимірах «рід вид», семантичного включення «частина - ціле» (наприклад, сонце - світило, земля - планета).

Старші підлітки (14-15 років) частіше використовують семантично суміжні асоціації, утворені за типом логічної ад'єктивації (abs_freq 13.7-11.1); ад'єктиваційні асоціації (від лат. adjektivum прикметник; різновид транспозиції, що обумовлює набуття іншими частинами мови синтаксичних функцій i категорійного 
значення прикметника) форматуються на засадах означення якісних характеристик смислового контенту похідного слова, наприклад, чемність - вихований (чоловік), сумніви - розгублений (погляд). Крім того, респонденти старшого підліткового віку вдаються до синтагматичного типу асоціативного смислотворення, використовуючи для означення відповіді словосполучення (abs_freq 10.6-10.5); у даному випадку вербалізовані значення сигніфікативного поля понять доповнюються ситуативним змістом через інференційні (від англ. inference - умовивід) зв'язки, котрі на концептуальному рівні дозволяють суб'єкту вийти за межі значення слова, а на когнітивному рівні - пов'язані із досвідом респондента, iз спроможністю «добудовувати» у свідомості логічні зв’язки на засадах узагальнених фонових знань.

Інші способи асоціативного смислотворення у протоколах емпіричного дослідження представлені несуттєво. Разом 3 тим, зіставлення кількісних показників абсолютної частоти використання способів асоціативного смислотворення підлітками виявило певні відмінності у порівнюваних групах i засвідчило нелінійність мовленнєво-мисленнєвого розвитку респондентів. Найбільше змін у логіці розгортання асоціативно-семантичного контенту прослідковується серед підлітків 14 років, що пов'язано iз кардинальним зміненням схем когнітивного опрацювання інформаційних потоків у період дорослішання.

Умовно можна виділити два періоди у розвитку логікосмислової організації мовленнєво-мисленнєвої діяльності підлітків:

1) 11-13 років (молодший і середній підлітковий вік), коли відбувається еволюційний розвиток мовленнєво-мисленнєвої діяльності, засвоюються навички логіко-смислової організації семантичного контенту;

2) 14-15 років (старші підлітки), період кардинальних зрушень у моделюванні суб'єктивного досвіду логіко-смислової організації мовленнєво-мисленнєвої діяльності, що спричиняє суперечливі тенденції асоціативного смислотворення: зменшується кількість асоціацій, утворених шляхом стандартного логічного упорядкування семантичного контенту мовної свідомості, зростає кількість суб'єктивних ідеосинкразичних асоціацій (зокрема - креативних (abs_freq 5,0 у підлітків 15 років проти abs_freq 0,5 серед підлітків 13 років)), i, разом 3 тим, збільшується вживаність формальних 
асоціацій (особливо - стереотипно-лексичних (abs_freq 8.8 серед 15-річних підлітків проти abs_freq 0.7 серед підлітків 13 років)).

Перевірка статистичної значущості відмінностей асоціативного розгортання семантичного контенту у мовленні підлітків була здійснена шляхом використання параметричного критерію-t Стьюдента для незалежних вибірок (Student's t-test) та однофакторного дисперсійного аналізу (Analysis of Variance). Результати статистичного етапу аналізу даних засвідчили (табл. 2), що відмінності між віковими групами підлітків у виявленні тенденцій розгортання асоціативно-семантичного контенту $\epsilon$ достовірно значущими відносно окремих предикторів логічного упорядкування мовленнєво-мисленнєвих вимірів свідомості (при $\mathrm{p} \leq 0,05)$.

Таблиця 2. Параметри статистичної достовірності відмінностей у способах асоціативного смислотворення між віковими групами респондентів

\begin{tabular}{|c|c|c|c|c|}
\hline \multirow[b]{2}{*}{ Типи асоціацій } & \multicolumn{2}{|c|}{$\begin{array}{c}\text { Значення } \\
\text { однофакторного } \\
\text { дисперсійного аналізу }\end{array}$} & \multicolumn{2}{|c|}{$\begin{array}{l}\text { t-критерій рівності } \\
\text { середніх Стьюдента }\end{array}$} \\
\hline & $\begin{array}{l}\text { F-критерий } \\
\text { Фішера }\end{array}$ & $\begin{array}{c}\text { Рівень } \\
\text { значимості } \\
\text { відмінностей } \mathrm{p} \\
\end{array}$ & $\mathrm{t}$ & $\begin{array}{c}\text { Рівень } \\
\text { значимості } \\
\text { відмінностей } \mathrm{p} \\
\end{array}$ \\
\hline \multicolumn{5}{|c|}{ Формальні асоціації } \\
\hline Об'єктивно-фонетичні & 1.973 & 0.038 & 0.522 & 0.05 \\
\hline Стереотипно-лексичні & 2.728 & 0.001 & 0.778 & 0.05 \\
\hline \multicolumn{5}{|c|}{ Семантичні асоціації } \\
\hline Семантично подібні & 1.423 & 0.237 & 0.627 & 0.631 \\
\hline Семантичного контрасту & 2.805 & 0.041 & 0.471 & 0.001 \\
\hline $\begin{array}{l}\text { Семантично суміжні } \\
\text { (приналежності) }\end{array}$ & 0.451 & 0.717 & 0.021 & 0.056 \\
\hline $\begin{array}{l}\text { Семантично суміжні } \\
\text { (підпорядкування) }\end{array}$ & 1.708 & 0.167 & 0.486 & 0.628 \\
\hline Семантично суміжні (тотожності) & 0.936 & 0.447 & 1.875 & 0.134 \\
\hline Семантично суміжні (ад’єктивації) & 1.891 & 0.132 & 0.200 & 0.842 \\
\hline \multicolumn{5}{|c|}{ Суб’сктивні (ідеосинкразичні) асоціації } \\
\hline Емоційно-оціночні & 4.436 & 0.002 & 0.576 & 0.050 \\
\hline Креативні & 3.168 & 0.017 & 0.460 & 0.001 \\
\hline \multicolumn{5}{|c|}{ Синтагматичні асоціації } \\
\hline $\begin{array}{l}\text { Синтаксичні конструкції } \\
\text { (словосполучення) }\end{array}$ & 3.853 & 0.005 & 0.801 & 0.001 \\
\hline $\begin{array}{l}\text { Синтаксичні конструкції } \\
\text { (речення) }\end{array}$ & 0.417 & 0.796 & 3.648 & 0.0001 \\
\hline
\end{tabular}


За означених умов передбаченої рівності дисперсій (див. табл. 2) t-критерій Стьюдента для незалежних вибірок $(p$-рівень $\leq 0,05)$ доводить, що у підлітків різних вікових груп статистично достовірно відрізняються кількісні показники абсолютної частоти використання способів асоціативного смислотворення за такими шкалами:

- формальні асоціації об'єктивно-фонетичного типу ( $\mathrm{t}=0,522$ при $p=0,05 \leq 0,05)$;

- формальні асоціації стереотипно-лексичного типу ( $\mathrm{t}=0,778$ при $p=0,05 \leq 0,05)$;

- семантичні асоціації за контрастом ( $\mathrm{t}=0,471$ при $p=0,001$ $0,05)$;

- суб'єктивні асоціації емоційно-оціночного типу ( $\mathrm{t}=0,576$ при $p=0,05 \leq 0,05)$;

- суб'єктивні асоціації креативного типу ( $\mathrm{t}=0,460$ при $p=0,001 \leq 0,05)$.

- синтагматичні конструкції рівня словосполучень (t=0,801 при $p=0,001-0,05)$.

Показники абсолютної частоти використання означених способів асоціативного смислотворення статистично достовірно вищі у вибірці старших підлітків 14-15 років; найбільшої значимості лінійна кореляція досягає між показниками асоціативного розгортання семантичного контенту серед підлітків 13-14 років. А отже можна стверджувати, що кардинальні зміни у схемах логікосмислової організації асоціативного мислення відбуваються iз достатньою мірою імовірності саме у період 13-14 років.

Сила взаємозв'язків між досліджуваними параметрами i змінною «Вікові групи» виявляється на достатньому $(0,3 \leq$ $\mathrm{t} \leq 0,5)$, середньому $(0,5 \leq \mathrm{t} \leq 0,7)$ і високому $(0,7 \leq \mathrm{t} \leq 0,9)$ рівнях статистичної значимості; високий рівень інтенсивності кореляційного зв'язку між віком респондентів і частотністю використання стереотипно-лексичних формальних асоціацій $(\mathrm{t}=0,778)$ та синтагматичних конструкцій рівня словосполучень $(\mathrm{t}=0,801)$ свідчить про сталість тенденції до стандартизації й уніфікації мовлення підлітків у процесі дорослішання. Завершення процедури первинної соціалізації особистості у 14-15 років на фоні достатнього рівня засвоєння досвіду мовленнєво-мисленнєвої діяльності (зокрема, й системи субкультурного соціолекту) 
призводить до зниження евристичного ресурсу інтелектуальної активності і поширення у мовленні школярів даної вікової групи стандартизованих кліше, через що у комплексі моделювання асоціативно-семантичного контенту актуалізується не семантичне значення слова-стимулу, а найбільш уживані (стереотипні) лексеми та сталі словосполучення.

Подальший аналіз результатів дослідження засвідчив, що інші форми моделювання асоціативно-семантичного контенту у порівнюваних групах не мають статистично значущих відмінностей $(\mathrm{p}>0,05)$, а отже прослідковується відносна сталість параметрів представлення змістових одиниць асоціативного поля мовної свідомості підлітків різного віку.

Порушення логіко-смислової організації асоціативносемантичного контенту мовлення підлітків представлені переважно повторенням похідного слова-стимулу (max abs_freq 4,3 у підлітків 13 років) та використанням для означення асоціативної реакції речення (max abs_freq 3.7 у підлітків 11-12 років), що може бути пояснено недостатнім рівнем розвитку навичок форматування смислових зв’язків між лексемами та аналізу смислових ярусів значення у межах семантичного поля; це компенсується намаганням заповнити «паузи нерішучості» та використанням синтагматично розгорнутих форм тлумачення смислової інформації. В цілому ж дані деструкції пов'язані не із віковими особливостями розвитку мовленнєво-мисленнєвої діяльності, а iз індивідуальною недостатністю мовленнєвої компетентності респондентів.

\section{Висновки}

Узагальнення даних теоретико-емпіричного дослідження проблеми моделювання асоціативно-семантичного контенту у вимірах логіко-смислової організації мовлення школярів підліткового віку надало підстави для таких висновків:

1. Динаміка розвитку навичок моделювання асоціативносемантичного контенту мовної свідомості протягом підліткового періоду означує сталість тенденцій стандартизації та уніфікації мовлення і згасання інтелектуальної ініціативи (про що свідчить зниження евристичного ресурсу й повернення до стимульнопродуктивного рівня інтелектуальної активності старших підлітків). 
2. Асоціативно-семантичні зв'язки у мовленні людини можна розглядати як індикатор вимірів логіко-смислового упорядкування змістових одиниць мовної свідомості суб'єкта смислотворення.

3. Недостатність досвіду встановлення асоціативносемантичних смислових зв'язків між лексемами та аналізу смислових ярусів значення слова у межах ментального простору й доступного семантичного поля спричиняє труднощі підлітків у адекватній вербалізації персональних домагань, через що відносини iз середовищем набувають афективного забарвлення.

4. У контексті означеного не викликає сумнівів той факт, що одним із важливих завдань психолого-педагогічного супроводу дорослішання дитини $\epsilon$ цілеспрямований розвиток мовленнєвомисленнєвих компетентностей; володіння підлітками прийомами логіко-смислової організації асоціативно-семантичного контенту мовлення постає водночас ефективним джерелом i умовою для задоволення особистісних потреб (потреб у толерантному діалозі, самопізнанні і самоствердженні) даної вікової групи.

5. Зорієнтованість навчальних програм вивчення мови у закладах середньої освіти на вирішення освітніх завдань рівня граматичного аналізу обумовлює закріплення у системі логікосмислової організації мовлення підлітків формальних операцій розумової діяльності, що $є$ гальмівним чинником, котрий ускладнює розвиток мовної свідомості і, відповідно, оптимальне формування комунікативних компетентностей особистості у період дорослішання.

6. Стимулювання евристичного рівнів інтелектуальної активності підлітків, навичок моделювання асоціативносемантичного контенту мовної свідомості потребує насиченого освітнього середовища, сповненого зразками конструктивної мовленнєво-мисленнєвої діяльності та об`єктивно новими продуктами цієї діяльності.

Виконане дослідження не вичерпує всіх аспектів проблемного поля розгортання асоціативно-семантичного континууму у вимірах логіко-смислової організації мовлення підлітків, але відкриває перспективи для подальшого його вивчення, зокрема - дослідження когнітивно-афективних механізмів розвитку мовної свідомості у підлітково-юнацькому середовищі. 


\section{Література}

Ахутина, Т.В. (2016). Смысл, смысловое поле и модель ситуации текста. Psycholinguistics. Психолінгвістика. Психолингвистика, 20(1), 15-26.

Бабенко, Л.Г., Васильев, И.Е., \& Казарин, Ю.В. (2000). Лингвистический анализ художественного текста. Екатеринбург.

Завершнева, Е.Ю. (2015). Представления о смысловом поле в теории динамических смысловых систем Л.С. Выготского. Bопросы психологи, 4, $119-135$.

Зінченко, О.В. (2016). Розвиток понятійного мислення підлітків у процесі Інтернет-спілкування. (Дис. канд. психол. наук). Київ.

Караулов, Ю.Н. (2010). Ассоциативная грамматика русского языка. Москва: Издво ЛКИ.

Леонтьев, Д.А. (2007). Психология смысла: природа, строение и динамика смысловой реальности. Москва: Смысл,

Лотман, Ю.М. (2010). Семиосфера. Санкт-Петербург: Искусство-СПб.

Романова, Т.В. (2017). Речевая самоидентификация по данным ассоциативного эксперимента. Политическая лингвистика, 6(66), 45-50.

Смульсон, М.Л. (2003). Психологія розвитку інтелекту. (Монографія). Київ: Нора-Друк.

Токарева, Н.М. (2015). Психологія комунікативного моделювання особистісних конструктів у підлітковому віці. (Дис. д-ра психол. наук). Київ.

Ушакова, Т.Н. (2011). Рождение слова: Проблемы психологии речи и психолингвистики. Москва: Институт психологии РАН.

Фомина, Н.А. (2014). Соотношение различных свойств языковой личности и особенностей ее речевой деятельности. Л.В. Засекина (Ред.), Язык, речь, личность в зеркале психолингвистики (с. 126-148). Луцк: Вэжа-Друк.

Фомина, Н.А., \& Орлов, В.Б. (2017). Речевая диагностика особенностей направленности личности подростков Psycholinguistics. Психолінгвістика. Психолингвистика, 22(1), 208-225. doi:10.5281/zenodo.1088406

Чепелева, Н.В. (2005). Социокультурные факторы понимания и интерпретации личного опыта. Н.В. Чепелєва (Ред.), Актуальні проблеми психології: Психологічна герменевтика, 2(5), 6-13. Київ: Міленіум.

Chomsky, N. (1968). Language and Mind. New York: Harcourt Brace Jovanovich, Inc.

Chrabaszcz, A., \& Gor, K. (2017). Quantifying Contextual Effects in Second Language Processing of Phonolexically Ambiguous and Unambiguous Words. Applied Psycholinguistics, 38(4), 909-942. doi: 10.1017/S0142716416000497

Fairclough, N. (1995). Critical Discourse Analysis. London: Longman.

Frank, St.L., \& Christiansen, M.H. (2018). Hierarchical and sequential processing of language. Language, Cognition and Neuroscience, 33(9), 1213-1218. doi:10.1080 /23273798.2018.1424347.

Ishida, T. (2018). Semantic Ambiguity Effects in L2 Word Recognition. Journal of Psycholinguistic Research, 47(3), 523-536. doi: 10.1007/s10936-017-9542-7

Spätgens, T., \& Schoonen, R. (2017). The semantic network, lexical access, and reading comprehension in monolingual and bilingual children: An individual differences study. Applied Psycholinguistics, 38(1), 225-256. doi: 10.1017/ S0142716417000224 


\section{References}

Ahutina, T.V. (2016). Smyisl, smyislovoe pole i model situatsii teksta [Meaning, semantic field and model of the situation of the text]. Psiholingvistika Psycholinguistics, 20(1), 15-26 [in Russian].

Babenko, L.G., Vasilev, I.E., \& Kazarin, Yu.V. (2000). Lingvisticheskiy analiz hudojestvennogo teksta [Linguistic Analysis of Artistic Text]. Yekaterinburg [in Russian].

Zavershneva, E.Yu. (2015). Predstavleniya o smyislovom pole v teorii dinamicheskih smyislovyih sistem L.S. Vyigotskogo [Ideas about the Semantic Field in the Theory of Dynamic Semantic Systems L.S. Vygotsky]. Voprosyi psihologii Psychology Issues, 4, 119-135 [in Russian].

Zinchenko, O.V. (2016). Rozvitok ponyattyevogo mislennya pidlitkiv u procesi Internet-spilkuvannya [Development of Conceptual Thinking of Adolescents in the Process of Internet Communication]. Candidate's thesis. Kyiv [in Ukrainian].

Karaulov, Yu.N. (2010). Assotsiativnaya grammatika russkogo yazyika [Associative Russian Grammar]. Moscow: LCI [in Russian].

Leontiev, D.A. (2007). Psihologija smysla: priroda, stroenie $i$ dinamika smyslovoj realnosti [Psychology of Meaning: Nature, Structure and Dynamics of the Semantic Reality.]. Moscow: Smysl [in Russian].

Lotman, Yu.M. (2010). Semiosfera [Semii Sphere]. Sankt-Peterburg: Yskusstvo-SPb. [in Russian].

Romanova, T.V. (2017). Rechevaya samoidentifikatsiya po dannyim assotsiativnogo eksperimenta [Speech self-identification according to an associative experiment]. Politicheskaya Lingvistika - Political Linguistics, 6(66), 45-50. [in Russian].

Smulson, M.L. (2003). Psihologiya rozvitku intelektu [Psychology of the Development of the Intellect]. Kyiv: Nora-Druk [in Ukrainian].

Tokareva, N.M. (2015). Psihologiya komunikativnogo modelyuvannya osobistisnih konstruktiv $\mathrm{u}$ pidlitkovomu vitsi [Psychology of Communicative Modeling of Personality Constructs in Adolescence]. Doctor's thesis. Kyiv [in Ukrainian].

Ushakova, T.N. (2011). Rozhdenie slova: problemy psihologii rechi $i$ psiholingvistiki [Birth of the Word: Problems of Speech Psychology and Psycholinguistics]. Moscow: Institut psihologii RAN [in Russian].

Fomina, N.A. (2014). Sootnoshenie razlichnyih svoystv yazyikovoy lichnosti i osobennostey ee rechevoy deyatelnosti [The Ratio of the Various Properties of the Language Personality and Features of its Speech Activity]. In L.V. Zasekina (Eds.), Yazyik, rech, lichnost $v$ zerkale psiholingvistiki - Language, Speech, Personality in the Mirror of Psycholinguistic (pp. 126-148). Lutsk: Veja-Druk [in Ukrainian].

Fomina, N.A., \& Orlov, V.B. (2017). Rechevaya diagnostika osobennostey napravlennosti lichnosti podrostkov [Speech Diagnostics of Personality Traits of Adolescents]. Psiholingvistika - Psycholinguistics, 22(1), 208-225 [in Ukrainian]. doi:10.5281/zenodo.1088406

Chepeleva, N.V. (2005). Sociokulturnye faktory ponimaniya i interpretacii lichnogo opyta [Socio-Cultural Factors in the Understanding and Interpretation of Personal Experience]. In N.V. Chepelyeva (Eds.), Aktualni problemi psihologiyi: Psihologichna Germenevtika - Actual Problems of Psychology: Psychological Hermeneutics, 2(3), 6-13. Kyiv: Milenium. 
Chomsky, N. (1968). Language and Mind. New York: Harcourt Brace Jovanovich, Inc. Chrabaszcz, A., \& Gor, K. (2017). Quantifying Contextual Effects in Second Language Processing of Phonolexically Ambiguous and Unambiguous Words. Applied Psycholinguistics, 38(4), 909-942. https://doi.org/10.1017/S0142716416000497

Fairclough, N. (1995). Critical Discourse Analysis. London: Longman.

Frank, St.L., \& Christiansen, M.H. (2018). Hierarchical and Sequential Processing of Language. Language, Cognition and Neuroscience, 33(9), 1213-1218. https://doi. org/10.1080/23273798.2018.1424347

Ishida, T. (2018). Semantic Ambiguity Effects in L2 Word Recognition. Journal of Psycholinguistic Research, 47(3), 523-536. https://doi.org/10.1007/s10936-0179542-7

Spätgens, T., \& Schoonen, R. (2017). The Semantic Network, Lexical Access, and Reading Comprehension in Monolingual and Bilingual Children: an Individual Differences Study. Applied Psycholinguistics, 38(1), 225-256. https://doi. org/10.1017/S0142716417000224

\section{АНОТАЦІЯ}

Вступ. Стаття присвячена аналізу тенденцій логіко-смислової організації мовленнєво-мисленнєвої діяльності підлітків у вимірах доступного семантичного простору та мовленнєвих компетентностей особистості. Констатовано, що інформація про світ систематизується свідомістю людини у вигляді асоціативно-вербального поля, продукування і моделювання якого $\epsilon$ одним із засобів репрезентації мовної компетентності суб'єкта життєтворення.

Матеріали і методики. У площині означеного виконано емпіричне дослідження особливостей розгортання семантичного контенту мовної свідомості підлітків у вимірі логіко-смислової організації мисленнєво-мовленнєвої діяльності за допомогою діагностичного потенціалу вільного асоціативного експерименту. Предметом дослідження була обрана система актуальних способів конструювання й асоціативного розширення смислів у семантичному полі мовної свідомості підлітків.

Результати. За результатами аналізу частотності використання типових асоціативних схем організації семантичного поля мовлення констатовано, що найбільш представленим серед підлітків є семантичний спосіб смислотворення, котрий базується на ідентифікаційних ознаках загального контуру словастимула на рівні значення. Доведено, що найбільще змін в логіці розгортання ассоціатівно-семантіческого контенту притаманно старшим підліткам; це інтерпретується як результат кардинальних змін в стратегіях когнітивної обробки інфрормаційних потоків.

Висновки. Зроблено висновок про сталість тенденції до стандартизації й уніфрікації мовлення підлітків у процесі дорослішання, означено зниження евристичного ресурсу інтелектуальної активності школярів старшого підліткового віку. у даному контексті цілеспрямоване формування мовленнєво-мисленнєвих компетентностей особистості, оволодіння підлітками ерективними прийомами логіко-смислової організації асоціативно- 
семантичного контенту мовлення визначається як необхідна передумова особистісного і мовно-мовленнєвого розвитку людини.

Ключові слова: мовленнєво-мисленнєва діяльність, мовна свідомість, логікосмислова організація мовлення, смислотворення, асоціативний зв'язок, вільний асоціативний експеримент, підлітковий вік, мовленнєвий розвиток.

\title{
Токарева Наталья. Моделирование ассоциативно-семантического контента в логико-смысловом измерении речи подростков
}

\begin{abstract}
АННОТАЦИЯ
Вступление. Статья посвящена анализу тенденций логіко-смысловой организации речемыслительной деятельности подростков в измерениях доступного семантического пространства и речевых компетенций личности. Констатировано, что информация о мире систематизируется сознанием человека в виде ассоциативно-вербального поля, продуцирование и моделирование которого является одним из средств репрезентации языковой компетентности субъекта жизнетворчества.
\end{abstract}

Материалы и методики. В контексте обозначенного выполнено эмпирическое исследование особенностей развертывания семантического контента языкового сознания подростков в измерении логіко-смисловой организации речемыслительной деятельности с помощью диагностического потенциала свободного ассоциативного эксперимента. Предметом исследования была выбрана система актуальных способов конструирования и ассоциативного расширения смыслов в семантическом поле языкового сознания подростков.

Результаты. В соответствии с результатами анализа частотности использования типичных ассоциативных схем организации семантического поля речи констатируется, что наиболее представленным среди подростков является семантический способ смыслообразования, основанный на идентификационных признаках общего контура слова-стимула на уровне значения. Доказано, что больше всего изменений в логике развертывания ассоциативно-семантического контента свойственно старшим подросткам; это интерпретируется как результат кардинальных изменений в стратегиях когнитивной обработки информационных потоков.

Выводы. Сделан вывод об устойчивости тенденции к стандартизации и унификации речи подростков в прочессе взросления, отмечено снижение эвристического ресурса интеллектуальной активности школьников старшего подросткового возраста. В данном контексте целенаправленное формирование речемыслительных компетентностей личности, усвоение подростками эфрфективных приемов логико-смысловой организации ассоциативносемантического контента речи определяется как необходимая предпосылка личностного и речемыслительного развития человека.

Ключевые слова: речемыслительная деятельность, языковое сознание, логикосмысловая организация речи, смыслообразование, ассоциативная связь, свободный ассоциативный эксперимент, подростковый возраст, речевое развитие. 